\title{
High incidence of herpes zoster in patients with systemic lupus erythematosus: an immunological analysis
}

Kohei Nagasawa, Yasuo Yamauchi, Yoshifumi Tada, Tomohiro Kusaba, Yoshiyuki Niho, Hiromi Yoshikawa

\begin{abstract}
The incidence of herpes zoster was determined in patients with systemic lupus erythematosus (SLE) and the cellular and humoral immunity to varicella zoster virus (VZV) investigated in 45 of these 92 patients.

The incidence of herpes zoster was high, occurring in 40 patients (43\%), though it was benign in all. Patients with SLE who had had zoster showed significantly higher antibody titres than normal subjects. On the other hand, only 13 of 43 (30\%) patients with SLE showed positive delayed hyersensitivity skin reactions to $\mathrm{VZV}$ antigen, despite a history of infections with VZV, whereas all 15 normal subjects had positive reactions. Skin reactions to VZV correlated directly with the ratio of OKT4 + to OKT8 + $T$ cells and inversely with the dose of corticosteroids.

These results suggest that the high incidence of herpes zoster in patients with SLE is probably due to defects in cellular immunity and that normal or higher titres of antibodies to VZV will not act as a preventive against zoster. In addition, reactivation of $\mathrm{VZV}$, whether symptomatic or not, seemed often to occur in patients with SLE.
\end{abstract}

Herpes zoster, a form of recurrent infection of varicella zoster virus (VZV), may often develop in elderly subjects ${ }^{12}$ and immunocompromised hosts. $^{3-6}$ The latter include patients with malignancies, especially lymphoproliferative diseases, and certain types of autoimmune diseases, such as systemic lupus erythematosus (SLE). ${ }^{3-5}$ The suppression of cellular immunity has been implicated in the pathogenesis of reactivation of $\mathrm{VZV}$, herpes zoster, because recurrent VZV infections occur in patients with antibodies against VZV. ${ }^{4} 7$

Immunological studies on patients with SLE showed a defective delayed hypersensitivity reaction $^{8-10}$ and a hyperactive humoral immunity. ${ }^{11} 12$ Corticosteroids or immunosuppressive treatments for SLE, or both, may lead to a further reduction in the host resistance to infections. ${ }^{13} 14$ The association of herpes zoster with SLE has not been fully studied, however, and there are few reports on it. ${ }^{15-19}$ During our 10 year observation of patients with SLE we have noted that herpes zoster occurs in patients with SLE much more commonly than generally expected.

We report here the incidence of herpes zoster in these patients with SLE, and the effects of immunological state on the pathogenesis of herpes zoster are discussed.

\section{Patients and methods}

PATIENTS WITH CONTROLS

Ninety two patients ( 89 women, three men) who fulfilled the criteria of the American Rheumatism Association for SLE ${ }^{20}$ were enrolled in this study. They had a mean age of 36.8 (range 19-68) years. The history of herpes zoster was obtained at interview with the patients and was confirmed by doctors' records. Cellular and humoral immunity to VZV was evaluated in 45 of these 92 patients (44 women and one man with a mean age of 37.2 (range 22-68) years) and in 15 healthy subjects with no history of zoster (11 women and four men with a mean age of $35 \cdot 0$ (23-52) years). Patients with a history of herpes zoster within the last six months were excluded from the immunological study. At the time of the immunological study 36 patients were receiving corticosteroids alone $(1 \cdot 25-30 \mathrm{mg} /$ day of prednisolone) and nine were receiving corticosteroids and immunosuppressants $(50 \mathrm{mg} /$ day of cyclophosphamide or azathioprine).

\section{ANTIBODY TO VZV}

Serum antibody titres to VZV antigen were measured by both the standard complement fixation technique ${ }^{21}$ and the neutralisation test, using the Kawaguchi strain of VZV and human embryonic lung cells as indicators.

\section{SKIN TESTING}

Varicella zoster virus antigen was prepared from the Oka strain. ${ }^{22}$ Skin testing with purified protein derivative $(0.5 \mu \mathrm{g} / \mathrm{ml}$, Nippon BCG Co, Tokyo, Japan) was also performed. A volume of $0.1 \mathrm{ml}$ of $\mathrm{VZV}$ antigen, purified protein derivative, and normal serine (control) was separately injected intradermally into the forearms and reactivity was measured at 48 hours. The response was recorded as millimetres of diameter of erythema or induration. A reaction was considered positive if the erythema or induration was $5 \mathrm{~mm}$ or more for VZV antigen and $10 \mathrm{~mm}$ or more for purified protein derivative.

\section{STATISTICS}

Categorical data were analysed by $\chi^{2}$ test with Yates's correction, and Student's $t$ test was used for the group comparisons.

\section{Results}

INCIDENCE OF HERPES ZOSTER IN PATIENTS WITH SLE

Forty of the 92 patients with SLE (43\%) had a history of herpes zoster and eight patients (9\%) 
Figure 1: Time distribution of occurrence of herpes zoster in relation to systemic lupus erythematosus (SLE).

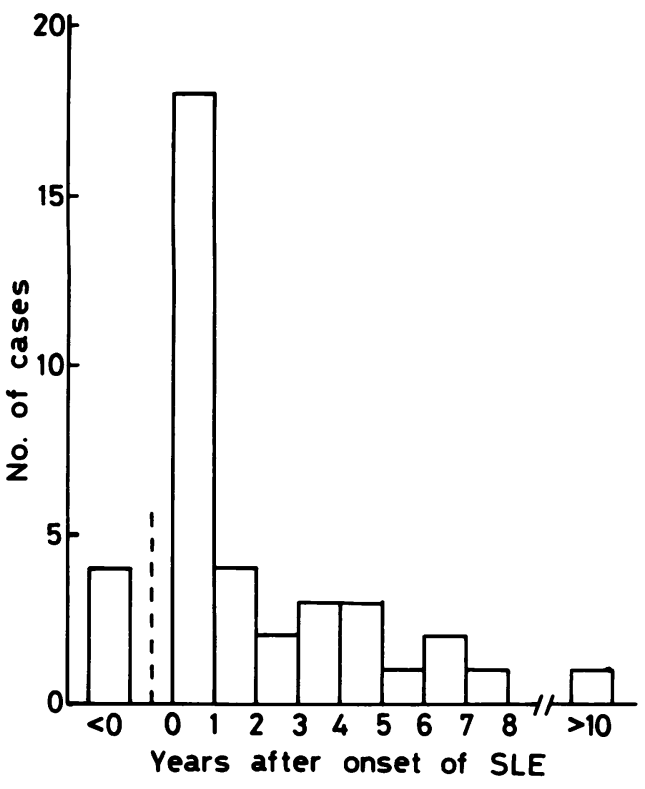

had its multiple episodes. The annual incidence of zoster in these 92 patients was $9 \cdot 1 \%$ (57 episodes of zoster in 623.1 cumulative years from the onset of SLE). The zoster was benign and localised in every patient and in no patient was there a generalised zoster. About half the patients had zoster in the year after the diagnosis of SLE had been made and many of the remaining patients had it in the chronic or inactive stage of SLE. It should be noted that four patients had zoster 1.5 to 10 years before SLE was diagnosed (fig 1). Their ages ranged from 21 to 32 (mean $24 \cdot 7$ ) years, younger than the average age of all the patients studied.

SERUM ANTIBODY TITRES TO VZV

To evaluate the humoral immunity to $\mathrm{VZV}$ in patients with SLE we measured the serum

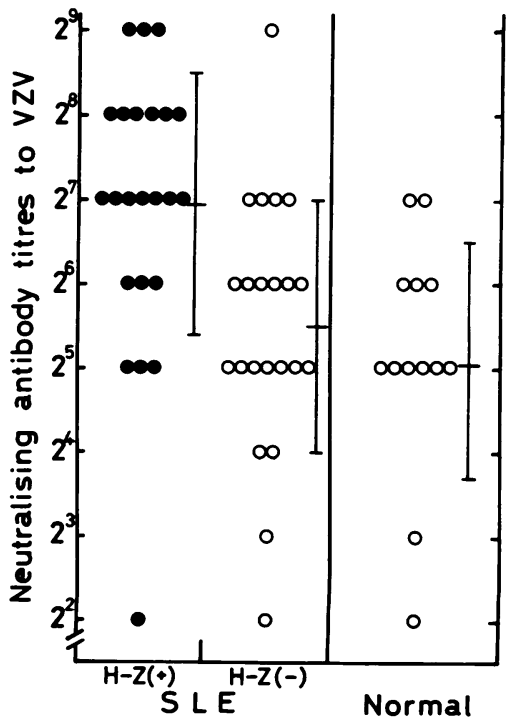

Figure 2: Antibody titres to varicella zoster virus (VZV) determined by the neutralisation test in patients with systemic lupus erythematosus (SLE) and in normal subjects. Horizontal bars represent means $(S D)$. The titres in patients with SLE and a history of zoster $(H-Z)$ are significantly higher than those in other groups $(p \geqslant 0.05)$

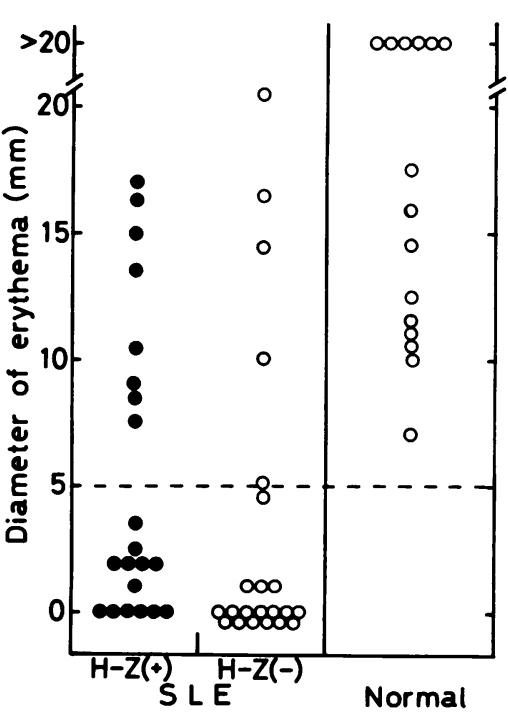

Figure 3: Delayed skin reactions to varicella zoster virus antigen. Varicella zoster virus antigen $(0.1 \mathrm{ml})$ was injected intradermally and the reaction was read 48 hours later. When a diameter of erythema or induration was $5 \mathrm{~mm}$ (horizontal dotted line) or more the reaction was considered to be positive.
Table 1: Antibodies to varicella zoster virus in patients with systemic lupus erythematosus (SLE) and in normal subjects determined by complement fixation

\begin{tabular}{llll}
\hline & $\begin{array}{l}\text { History of } \\
\text { zoster }\end{array}$ & $\begin{array}{l}\text { No of } \\
\text { patients } \\
\text { tested }\end{array}$ & $\begin{array}{l}\text { No (\%) of antibody } \\
\text { positive patientsł }\end{array}$ \\
\hline SLE & $(+)$ & 23 & $20(87)^{*}$ \\
SLE & $(-)$ & 22 & $10(45) \dagger$ \\
Normal & $(-)$ & 13 & $3(23)$
\end{tabular}

*Significantly higher than the other two groups $(p<0.01)$ tSignificantly higher than the normal group $(p<0.05)$. Antibody determined by complement fixation was considered positive when the titre was $1 / 4$ or higher.

antibody titres to VZV by complement fixation and the neutralising test. Antibody determined by complement fixation is known to be detected rather transiently. ${ }^{23}$ Table 1 shows that the antibody to VZV determined by complement fixation was detectable $(>4)$ in only three of 13 (23\%) normal subjects, an incidence lower than the $45 \%(10 / 22)$ in patients with SLE and no history of herpes zoster $(p<0.05)$. In contrast, as many as 20 of $23(87 \%)$ patients with SLE and a history of zoster had antibody detected by complement fixation with titres up to $1 / 256$. Figure 2 shows the antibody titres to VZV detected by the neutralising test. All patients with SLE and normal subjects had titres of antibodies detectable by the neutralising test. The mean titres in patients with SLE without herpes zoster and normal subjects were $2^{5 \cdot 5}$ and $2^{5 \cdot 1}$ respectively, with no statistically significant difference. On the other hand, the mean titre in patients with SLE and a history of zoster was $2^{6.9}$, a significantly higher value than in the other two groups $(\mathrm{p}<0.05)$.

DELAYED SKIN REACTIONS TO VZV ANTIGEN

Figure 3 shows the results of delayed skin test with VZV antigen. When a diameter of $\geqslant 5 \mathrm{~mm}$ of erythema or induration at $\mathbf{4 8}$ hours was taken as positive, all of $15(100 \%)$ normal subjects showed positive reactions. In contrast, only eight of $21(38 \%)$ patients with SLE and a history of herpes zoster and five of 22 (23\%) patients with no history had positive reactions $(p<0.01)$. The size of the erythema was larger in the normal subjects than in the group with SLE. To determine whether the depressed skin reactivity would be limited to or specific for VZV antigen a skin test was carried out using the purified protein derivative antigen. The results were similar to those with VZV-only five of $42(12 \%)$ patients with SLE showed positive reactions to purified protein derivative, in contrast with the high incidence of $13 / 15$ $(87 \%)$ in the normal subjects $(p<0.01)$. In no patient tested was there a history of tuberculosis. These results indicate that the delayed hypersensitivity is generally depressed in patients with SLE and that herpes zoster does not augment the delayed skin reactivity to VZV antigen in these patients when tested more than six months after experiencing zoster.

All the patients with SLE were receiving corticosteroids, compounds considered to exert an inhibitory effect on skin reactions. ${ }^{24}$ In the patients receiving less than $10 \mathrm{mg} /$ day of 
Table 2: Effect of corticosteroids on skin reactions to varicella zoster virus

\begin{tabular}{lll}
\hline $\begin{array}{l}\text { Dose of } \\
\text { prednisolone } \\
\text { (mg/day) }\end{array}$ & $\begin{array}{l}\text { No of } \\
\text { patients }\end{array}$ & $\begin{array}{l}\text { No (\%) of positive } \\
\text { skin reactions }\end{array}$ \\
\hline$\geqslant 10$ & 27 & $3(11)^{*}$ \\
$<10$ & 16 & $10(63)$ \\
\hline
\end{tabular}

${ }^{*}$ Significantly lower $(p<0 \cdot 05)$.

Table 3: Correlation between OKT4/8 ratio and skin reactions to varicella zoster virus

\begin{tabular}{lll}
\hline OKT4/8 ratiof & $\begin{array}{l}\text { No of } \\
\text { patients }\end{array}$ & $\begin{array}{l}\text { No (\%) of positive } \\
\text { skin reactions }\end{array}$ \\
\hline$<0.5$ & 17 & $3(18)^{*}$ \\
$0.5-1.0$ & 15 & $5(33)$ \\
$>1.0$ & 11 & $6(55)^{*}$ \\
\hline
\end{tabular}

"Significantly different $(p<0.05)$ from each other.

†The OKT4/8 ratio was assayed using peripheral lymphocytes when the skin test was performed.

prednisolone 10 of $16(63 \%)$ had positive skin reactions to $\mathrm{VZV}$, whereas only three of 27 (11\%) patients receiving $10 \mathrm{mg} /$ day or more prednisolone showed positive reactions (table 2). Nine of 45 patients were treated with immunosuppressive drugs (cyclophosphamide or azathioprine, $50 \mathrm{mg} /$ day for each) together with corticosteroids. There was no difference, however, in skin reactions to VZV between the patients receiving immunosuppressive drugs and those not receiving them (data not shown).

In delayed hypersensitivity skin reactions $T$ cells, preferentially CD4 (OKT4+) cells, and macrophages are considered to be involved..$^{25}$ We investigated the correlation between skin reactions to VZV and the OKT4/8 ratio in patients with SLE (table 3). As shown, the positivity of skin reactions correlated with the $\mathrm{T} 4 / \mathrm{T} 8$ ratio. In patients with a $\mathrm{T} 4 / \mathrm{T} 8$ ratio of 1.0 or more the number of those with positive skin test was higher than that in those with a T4/T8 ratio of less than $0.5(p<0.05)$.

\section{Discussion}

The annual incidence of herpes zoster is estimated to be less than $0.5 \%$ of the general population, ${ }^{26} 27$ and most are elderly ${ }^{2829}$ or immunosuppressed subjects. ${ }^{1}{ }^{30}$ In patients with SLE the incidence of zoster reported in Western countries is $3 \cdot 2-21 \% .{ }^{14-16} 18$ We found that herpes zoster occurred in patients with SLE with an incidence of $43 \%$ and an annual incidence of $9 \%$. These figures are extremely high compared with those mentioned above. Our patients were consecutively followed up in the outpatient clinic of Kyushu University Hospital and were not specifically selected. Two other groups of investigators in Japan have reported that the incidence of zoster was $43 \%$ and $40 \%$ respectively, ${ }^{17} 19$ similar to the findings for our patients. Thus Japanese patients with SLE seem to be much more susceptible to herpes zoster than their white counterparts.

In developed temperate regions over $90 \%$ of the population are infected with VZV by the age of $20,,^{28}$ and these subjects show a delayed type skin reaction to VZV antigen 222931 with an antibody to VZV when assessed by a sensitive technique. ${ }^{28}$ Suppression of cellular immunity has been implicated in the pathogenesis of reactivation of this virus, a form of herpes zoster. $^{3-629}$ To evaluate cellular immunity to VZV techniques used include $T$ cell transformation, ${ }^{237}$ interferon production, ${ }^{7}$ killer cell activity, ${ }^{4}$ and delayed hypersensitivity skin reactions. ${ }^{22} 2932$ The delayed skin test is of great value in the overall assessment of cellular immunity. ${ }^{33}$ This method enables assessment of the function of T cells, mainly CD4 (OKT4+) cells, as well as of macrophages. ${ }^{25}{ }^{34}$ Immunological studies in patients with SLE have shown defective delayed type hypersensitivity reactions and, conversely, hyperactive humoral immunity. ${ }^{8-12}$ We found that the delayed skin reactions to VZV antigen were depressed in patients with SLE and even in those who had had herpes zoster, yet all the normal subjects showed strongly positive reactions. As four young patients had had zoster before the development of SLE, immune dysfunctions might have occurred long before SLE became apparent, though there is no direct evidence.

Corticosteroids, which are prescribed for most patients with SLE, also affect the immune states of patients. Corticosteroids suppress delayed hypersensitivity skin reactions probably by inhibiting the effect of macrophage migration inhibition factor, produced by CD4 (OKT4+) cells, on macrophages. ${ }^{24}$ According to our study, $10 \mathrm{mg} /$ day of prednisolone seems to be the borderline dose. Although immunosuppressive drugs such as cyclophosphamide and azathioprine given to nine patients in a dose of $\mathbf{5 0}$ $\mathrm{mg} /$ day seemed to have little effect on the skin test and antibody response, the evaluation was difficult because of small numbers. Our results also indicate that the skin reactions correlated with the OKT $4 / 8$ ratio in patients with SLE. In untreated patients with SLE decreased CD4 and normal or increased CD8 cells are often noted. ${ }^{36} 37$ Corticosteroid treatment preferentially decreases CD4 cells and thus decreases the T4/T8 ratio. ${ }^{37}{ }^{38}$ In our study the number of patients with SLE with a T4/T8 ratio over 1.0 accounted for only 11 of the 43 tested (26\%). This low ratio may explain the poor skin reactions to VZV and the high incidence of zoster.

Sensitivity of the antibody detected by complement fixation is poor compared with that detected by the neutralising test, and in normal subjects the former disappears within one year after a primary infection whereas the latter is detectable for a lifelong period. ${ }^{23}$ Our results indicated, however, that the increased antibody titre detected by complement fixation was found more often in patients with SLE, even in those with no history of zoster, than in normal subjects. Although all the patients and the normal subjects had antibody detectable by the neutralising test, patients with SLE and a history of zoster showed significantly higher titres of the antibody. These findings suggest that patients with SLE can have a normal or even better antibody response to VZV than normal subjects. This may be consistent with the hypothesis that polyclonal B cell activation usually occurs in patients with SLE ${ }^{11}$ or 
suggest that reactivation of $\mathrm{VZV}$ without overt clinical manifestations might sometimes occur in patients with SLE because of impairment of cellular immunity. Corticosteroids (1·25-30 $\mathrm{mg} /$ day) do not seem to affect the antibody response to $\mathrm{VZV}$, a finding consistent with reported data indicating that low doses of corticosteroids have no inhibitory effects on antibody formation. ${ }^{39}$ The high incidence of zoster despite the presence of humoral antibody may indicate that the presence of the antibody to VZV will probably not prevent zoster. Normal or even higher antibody titres to VZV in patients with SLE may inhibit the generalisation of zoster as Mazur et al suggested, ${ }^{5}$ which is often seen in patients with lymphoproliferative diseases. ${ }^{5} 40$

Taken together, we conclude that the very high incidence of herpes zoster in patients with SLE may be due to an impaired cellular immune response because of the underlying disease and as the result of corticosteroid treatment. In addition, an even higher antibody response to VZV, which is either caused by the reactivation of $\mathrm{VZV}$ or is a part of polyclonal $\mathrm{B}$ cell activation in SLE, may not inhibit the development of herpes zoster.

We thank Dr M Takahashi, Research Institute of Microbial Diseases, Osaka University for providing the VZV antigen, and M Ohara for comments on the manuscript. This work was supported in part by a grant in aid from the Ministry of Healt and Welfare, Japan, for research on autoimmune diseases.

1 Burgoon C F, Jr, Burgoon J S, Baldridge C D. The natural history of herpes zoster JAMA 1957; 164: 265-9.

2 Miller A E. Selective decline in cellular immune response to varicella-zoster in the elderly. Neurology 1980; 30: 582-7.

3 Arvin A M, Polland R B, Rasmussen L E, Merigan T C. Selective impairment of lymphocyte reactivity to varicella zoster virus antigen among untreated patients with lymphoma. 7 Infect Dis 1978; 137: 531-40.

4 Gershon A A, Steinberg S P. Cellular and humoral immune responses to varicella-zoster virus in immunocompromised patients during and after varicella-zoster infections. Infect Immun 1979; 25: 170-4

5 Mazur M H, Whitley R J, Dolin R. Serum antibody levels as risk factors in the dissemination of herpes zoster. Arch Intern Med 1979; 139: 1341-5.

6 Weller T H. Varicella and herpes zoster. Changing concepts of the natural history, control, and importance of a not-sobenign virus (second of two parts). N Engl f Med 1983; 309: $1434-40$.

7 Arvin A M, Polland R B, Rasmussen L E, Merigan T C Cellular and humoral immunity in the pathogenesis of
recurrent herpes viral infections in patients with lymphoma. recurrent herpes viral infections in

8 Horwitz D A. Impaired delayed hypersensitivity in systemic lupus erythematosus. Arthritis Rheum 1972; 15: 353-9.

9 Hahn B H, Bagby M K, Osterland C K. Abnormalities of delayed hypersensitivity in systemic lupus erythematosus. Am f Med 1973; 55: 25-31.

10 Rosenthal C J, Franklin E C. Depression of cellular-mediated immunity in systemic lupus erythematosus. Relation to disease activity. Arthritis Rheum 1975; 18: 207-17.

11 Hurd $E$, Dowdle $W$, Casey $H$, Ziff $M$. Virus antibody levels in systemic

12 Blaese R M, Grayson J, Steinberg A D. Increased immunoglobulin-secreting cells in the blood of patients with active globulin-secreting cells in the blood of patients with active

13 Pillay V K G, Wilson D M, Ing T S, Kark R M. Fungus infection in steroid-treated systemic lupus erythematosus. fAMA 1968; 205: 261-5.
14 Ginzler E, Diamond H, Kaplan D, Weiner M, Schlesinger $M$, Seleznick $M$. Computer analysis of factors influencing frequency of infection in systemic lupus erythematosus. Arthritis Rheum 1978; 21: 37-44

15 Dubois E L, Tuffanelli D L. Clinical manifestations of systemic lupus erythematosus. Computer analysis of 520 cases. FAMA 1964; 190: 104-11.

16 Vachtenheim J, Grossmann J. The herpetic viral diseases and systemic

17 Hamaguchi T, Kotani Y, Imanaka S, Morito S, Kawamura Y, Shimizu M. Lupus erythematosus and herpes zoster. Mie Medical fournal 1970; 19: 189-92.

18 Moutsopoulos H M, Gallagher J D, Decker J L, Steinberg A D. Herpes zoster in patients with systemic lupus A D. Herpes zoster in patients with systemic

19 Ishigatsubo Y, Tani K, Sakamoto H, et al. Herpes zoster in patients with SLE. Fapanese foumal of Infectious Diseases 1982; 56: 272-7.

20 Tan E G, Cohen A S, Fries J F, et al. The 1982 revised criteria for the classification of systemic lupus erythematosus. Arthritis Rheum 1982; 25: 1271-7.

21 Sever J L. Application of a microtechnique to viral serological investigations. I Immunol 1962; 88: 320-9.

22 Kamiya H, Ihara T, Hattori A, et al. Diagnostic skin test reactions with varicella virus antigen and clinical applications of the test. $\mathcal{J}$ Infect Dis 1977; 136: 784-8.

23 Brunell P A. Varicella-zoster virus. In: Mandell G L, Douglas R G Jr, Bennett J E, eds. Principles and practice of infectious diseases. New York: Wiley, 1985: 952-60.

24 Fauci A S, Dale D C, Balow J E. Glucocorticosteroid therapy: mechanisms of action and clinical considerations. Ann Intern Med 1976; 84: 304-15.

25 Scheynius A, Klaresckog L, Forsum U. In situ identification of T lymphocyte subsets and HLA-DR expressing cells in the human skin tuberculin reaction. Clin Exp Immunol 1982; 49: 325-30.

26 Hope-Simpson R E. The nature of herpes zoster: a long-term study and a new hypothesis. Proc $R$ Soc Med 1965; 58: 9-20.

27 Ragozzino M W, Melton III L J, Kurland L T, Chu C P, Perry $H$ O. Population-based study of herpes zoster and its Perry H O. Population-based study of herpes zo

28 Weller T H. Varicella and herpes zoster. Changing concepts of the natural history, control, and importance of a not-so-
benign virus (first of two parts). $N$ Engl $\mathcal{Y}$ Med 1983; 309: benign

29 Burke B L, Steele R W, Beard O W, Wood J S, Cain T D, Marmer D J. Immune responses to varicella-zoster in the aged. Arch Intern Med 1982; 142: 291-3.

30 Wright E T, Winter L H. Herpes zoster and malignancy. Arch Dermatol 1961; 84: 242-4.

31 Baba K, Yabuuchi H, Okuni H, Takahashi M. Studies with live varicella vaccine and inactivated skin test antigen: protective effect of the vaccine and clinical application of the skin test. Pediatrics 1978; 61: 550-5.

32 Nagafuchi $\mathrm{S}$, Iwahashi $\mathrm{T}$, Higa $\mathrm{K}$, et al. Delayed type hypersensitivity (DTH) skin reaction to varicella-zoster hypersensitivity (DTH) skin reaction to varicella-zoster virus antigen in patients with systemic lupus ery

33 Stites D P. Clinical laboratory methods of detection of cellular immune function. In: Stites DP, Stobo J D, Fudenberg $\mathrm{H} \mathrm{H}$, Wells $\mathrm{J} \mathrm{V}$, eds. Basic and clinical immunology. Drawer L Los Altos: Lange Medical Publications, 1982: 366-83.

34 Unanue $\mathbf{E} \mathbf{R}$. The regulatory role of macrophages in antigenic stimulation. Part two: Symbiotic relationship between lymphocytes and macrophages. Adv Immunol 1981; 31: $1-136$.

35 Rinehart J J, Wuest D, Ackerman G A. Corticosteroid alteration of human monocyte to macrophage differentiation. f Immunol 1982; 129: 1436-40.

36 Smolen J S, Chused T M, Leiserson W M, Reeves J P, Alling $D$, Steinberg A D. Heterogeneity of immunoregulatory Tcell subsets in systemic lupus erythematosus. Correlation with clinical features. Am $\mathcal{J}$ Med 1982; 72: 783-90.

37 Horwitz D A. Lymphocytes and immune regulation in systemic lupus erythematosus. In: Wallace $D \mathrm{~J}$, Dubois E L, eds. Dubois' lupus erythematosus. 3rd ed. Philadelphia: Lea and Febiger, 1987: 194-210.

38 Bakke A C, Kirkland P A, Kitridou R C, et al. T lymphocyte subsets in systemic lupus erythematosus. Correlations with corticosteroid therapy and disease activity. Arthritis Rheum 1983; 26: 745-50.

39 Cupps T R, Edgar L C, Thomas C A, Fauci A S. Multiple mechanisms of $B$ cell immunoregulation in man after administration of in vivo corticosteroids. $\mathcal{F}$ Immunol 1984 132: 170-5.

40 Dolin R, Reichman R C, Mazur M H, Whitley R J. Herpes Ann Intern Med 1978; 89: 375-88. 